\title{
Pengaruh Model Teams Games Tournament (TGT) Dilengkapi LDS Terhadap Minat dan Hasil Belajar Kognitif Siswa Pada Materi Mikroorganisme di Vaishnavi Secondary School Nepal
}

\author{
Lukman Hakim ${ }^{1}$, Sri Mulyani Endang Susilowati ${ }^{2}$ \\ ${ }^{1,2}$ Universitas Negeri Semarang-Kampus Sekaran, Kelurahan Sekaran \\ Kecamatan Gunungpati 50229
}

\begin{abstract}
Penelitian ini bertujuan untuk mengetahui pengaruh penerapan model pembelajaran Teams Games Tournament (TGT) dilengkapi LDS terhadap minat dan hasil belajar kognitif pada materi mikroorganisme di Vaishnavi Secondary School Nepal. Penelitian ini merupakan penelitian pre-experimental dengan pola One-Group Pretest-Posttest Design. Populasi dalam penelitian ini adalah seluruh siswa di Vaishnavi Secondary School yaitu pada Low Secondary School setingkat SMP dengan sampel siswa kelas 8 yang berjumlah 14 siswa sebagai kelas eksperimen yang diambil secara langsung melalui kepala sekolah. Metode pengumpulan data dalam penelitian ini adalah angket, dokumentasi, observasi, dan tes. Data yang diambil berupa hasil belajar kognitif, minat belajar dan aktivitas siswa berupa observasi aktivitas siswa dan tanggapan siswa. Analisis data hasil penelitian menggunakan uji N-gain dan ketuntasan klasikal 85\% pada hasil belajar kognitif, angket minat belajar dan aktivitas siswa digunakan analisis deskriptif. Berdasarkan hasil belajar kognitif siswa rerata pretest 45,43 sedangkan rerata posttest 66,78 dengan ketuntasan klasikal $85,7 \%$ sedangkan pada uji $\mathrm{N}$-gain diperoleh $64,3 \%$ kategori sedang dan 35,7\% kategori rendah dengan rerata peningkatan sedang sebesar 0,381. Analisis angket minat belajar rerata sebelum treatment 60,1 kategori sedang meningkat menjadi 67,37 kategori tinggi setelah treatment. Analisis aktivitas belajar siswa dari kurang aktif dengan rerata 29,08 menjadi cukup aktif dengan rerata 47,96\% kemudian mengalami peningkatan rerata $62,75 \%$ kategori aktif. Dari tanggapan siswa mengenai aktivitas siswa sejumlah 92,86\% memberikan tanggapan baik dan $7,14 \%$ cukup baik. Hasil penelitian ialah penerapan pembelajaran model TGT dilengkapi LDS memberikan pengaruh positif terhadap minat dan hasil belajar kognitif siswa pada materi mikroorganisme.
\end{abstract}

Kata kunci: Hasil Belajar Kognitif; LDS; Minat Belajar; Model Pembelajaran TGT. 


\section{PENDAHULUAN}

Pendidikan adalah salah-satu tolak ukur dari keberhasilan suatu bangsa. Bangsa yang bagus ditandai dengan kualitas pendidikan yang bagus pula. Menurut Marwiyah (2012), pendidikan merupakan usaha sadar dan terencana dalam pembelajaran agar siswa aktif mengembangkan potensi diri. Dengan proses pendidikan maka suatu bangsa dapat mencapai kemajuan diberbagai bidang kehidupan.

Salah-satu kajian bidang dasar IPA adalah biologi. Pembelajaran biologi yang berupa konsep dan teori cukup menyulitkan siswa dalam memahami materi karena sifatnya yang hafalan sehingga menyebabkan siswa merasa bosan. Menurut Putrayasa dkk. (2014), IPA merupakan salah-satu mata pelajaran yang sangat penting untuk diberikan pada setiap jenjang pendidikan sehingga diperlukan adanya upaya oleh guru dalam proses pembelajaran yang efektif dan aktif.

Pembelajaran IPA Biologi di Vaishnavi Secondary School Nepal masih menggunakan pembelajaran konvensional dan bersifat teacher centered learning sehingga proses kegiatan belajar berpusat pada guru. Guru hanya menyampaikan materi di dalam kelas sehingga siswa kurang aktif dalam mengikuti pembelajaran. Berdasarkan hasil belajar siswa tergolong masih rendah, sebagian besar siswa masih berada di bawah KKM yang ditetapkan sekolah sebesar 60. Selain itu, 10 dari 14 siswa mengatakan bahwa materi makhluk hidup terutama materi mikroorganisme merupakan materi yang paling sulit. Padahal pemerintah Nepal telah membentuk Nepal National Education Planning Commision (NNEPC) yang meminta diimplementasikannya suatu pembelajaran yang aktif, perencanaan kooperatif antara guru dan siswa, prinsip child-centered-learning dan mengharuskan adanya penerapan cooperative learning.

Pembelajaran dengan metode ceramah membuat siswa merasa bosan dan kurang adanya minat siswa dalam belajar. Kurangnya minat siswa akan mengakibatkan siswa tidak senang, kurang terlibat dalam aktivitas belajar maupun tidak tertarik dalam belajar. Menurut Astuti (2015), minat merupakan tenaga atau dorongan penggerak yang dipercaya ampuh dalam proses belajar yang berhubungan dengan perasaan suka dan tidak suka, tertarik atau tidak tertarik. Minat merupakan suatu rasa lebih suka dan rasa keterikatan pada suatu hal atau aktivitas tanpa ada yang menyuruh yang pada dasarnya penerimaan hubungan antara siswa dan sesuatu di luar diri siswa sehingga semakin kuat atau dekat hubungan maka akan semakin besar minat (Maesaroh, 2013) lebih lanjut lagi 
bahwa minat adalah pendorong dalam melaksanakan setiap aktivitas (Nurjanah \& Aman, 2016). Minat adalah kesadaran seseorang tehadap suatu objek, seseorang, suatu soal atau situasi yang terdapat hubungan dengan dirinya (Kholisho, 2017). Secara tidak langsung dengan adanya minat siswa secara sadar akan mempersiapkan dirinya dalam pembelajaran. Belajar siswa dapat terlaksana dengan baik, apabila didorong oleh minat yang besar yang dapat dimunculkan dengan cara bagaimana guru dalam mengajar. Berdasarkan pengertian tersebut, terdapat 5 hal yang digunakan untuk mengukur minat belajar siswa diantaranya: 1) perasaan senang, 2) ketertarikan siswa, 3) perhatian siswa, 4) keterlibatan siswa, dan 5) kesadaran siswa.

Peningkatkan minat belajar yang rendah dapat dilakukan dengan melakukan proses pembelajaran yang menyenangkan bagi siswa. Model pembelajaran yang diterapkan adalah model pembelajaran kooperatif. Salah-satu model pembelajaran yang bisa dipakai berupa model Teams Games Tournament (TGT). Muldayanti (2013) mengatakan bahwa pembelajaran kooperatif TGT dapat meningkatkan dan menumbuhkan minat belajar siswa terutama pada materi Biologi karena di dalam pembelajaran TGT terdapat unsur proses permainan yang menjadikan proses pembelajaran akan lebih menyenangkan. Hamid dkk. (2014), model pembelajaran TGT dilaksanakan dengan membagi siswa menjadi beberapa kelompok belajar, terdiri atas 4-5 orang yang berbeda-beda tingkat kemampuan, jenis kelamin, dan latar belakang etniknya menjadi satu kelompok tanpa membedakan siswa yang satu dengan yang lainnya. Ghalia dkk (2015), model pembelajaran TGT terdiri atas 5 komponen utama: 1) presentasi kelas, 2) belajar kelompok, 3) games, 4) tournament, dan 5) penghargaan (rekognisi). Dalam memacu kegairahan minat siswa dalam belajar maka diperlukan suatu media khusus sebagai perangsang siswa untuk belajar. Media yang digunakan dalam penelitian ini tidak lain adalah Lembar Diskusi Siswa (LDS).

Lembar Diskusi Siswa (LDS) merupakan media yang diberikan guru kepada siswa di suatu kelas atau kelompok untuk melakukan aktivitas belajar siswa. Utami dkk. (2018), salah-satu fungsi dari LDS adalah sebagai arahan proses pembelajaran dan memotivasi siswa agar tidak mudah bosan dalam mengikuti proses pembelajaran serta mampu meningkatkan minat belajar siswa. Penggunaan media LDS dalam pembelajaran model TGT dapat digunakan oleh guru sebagai alat agar siswa lebih memahami materi dalam kegiatan pembelajaran. 
Berdasarkan uraian di atas, maka penelitian ini bertujuan untuk mengetahui: 1) pengaruh model Teams Games Tournament (TGT) dilengkapi LDS terhadap hasil belajar kognitif siswa pada materi mikroorganisme di Vaishnavi Secondary School Nepal dan 2) pengaruh model Teams Games Tournament (TGT) dilengkapi LDS terhadap minat belajar siswa di Vaishnavi Secondary School Nepal.

\section{METODE PENELITIAN}

Populasi dalam penelitian adalah seluruh siswa di Vaishnavi Secondary School Nepal yaitu Low Secondary School (kelas 6-8) setingkat SMP. Sampel dalam penelitian adalah siswa kelas 8 yang berjumlah 14 siswa yang ditentukan langsung oleh kepala sekolah sebagai kelas eksperimen. Penelitian yang dilaksanakan menggunakan metode kuantitatif dan jenis penelitian yaitu pre-experimental dengan bentuk One-Group PretestPosttest Design.

$$
\mathrm{O}_{1} \mathrm{X} \mathrm{O}_{2}
$$

\section{Gambar 1 Bentuk Penelitian One-Group Pretest-Posttest Design} Keterangan:

$\mathrm{O}_{1}$ : Keadaan sebelum perlakuan (hasil pretest dan minat belajar siswa)

$\mathrm{O}_{2}$ : Keadaan setelah perlakuan (hasil posttest dan minat belajar siswa)

X : Perlakuan (Model Teams Games Tournament (TGT) Dilengkapi LDS)

Variabel bebas dalam penelitian ini adalah model pembelajaran Teams Games Tournament (TGT) sedangkan variabel terikat dalam penelitian ini adalah minat belajar siswa dan hasil belajar kognitif siswa kelas 8 pada materi mikroorganisme di Vaishnavi Secondary School Nepal setelah penerapan model pembelajaran Teams Games Tournament (TGT).

Metode pengambilan data yang digunakan dalam penelitian ini adalah metode tes, angket, observasi dan dokumentasi. Instrumen penelitian yang digunakan yaitu tes dan non tes. Soal tes digunakan untuk mengukur hasil belajar kognitif adalah soal pilihan ganda yang disusun berdasarkan Taksonomi Bloom. Tes yang sudah disusun diukur validitas, tingkat kesukaran, daya beda dan reliabilitas. Instrumen non tes meliputi angket minat belajar siswa, angket tanggapan aktivitas siswa dan lembar observasi aktivitas 
belajar siswa. Instrumen aktivitas digunakan sebagai data pendukung pembelajaran dalam penelitian.

Analisis data yang dilakukan yaitu mengenai hasil belajar kognitif menggunakan uji N-gain dan ketuntasan klasikal minimal 85\% dari hasil pretest dan posttest, angket minat belajar dianalisis secara deskriptif yang dilakukan di awal dan akhir treatment, lembar observasi dan tanggapan aktivitas belajar siswa dianalisis secara deskriptif.

\section{HASIL DAN PEMBAHASAN}

\section{Hasil Belajar Kognitif Siswa}

Data hasil belajar kognitif siswa diambil dari nilai pretest dan posttest. Dari hasil belajar tersebut ditetapkan ketuntasan klasikal dan nilai N-gain. Grafik ketuntasan klasikal disajikan pada gambar 2 sebagai berikut:

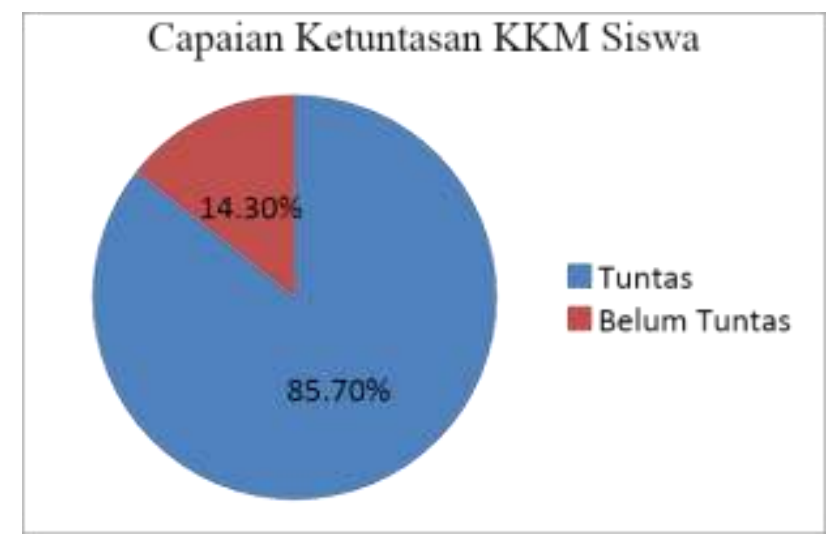

Gambar 2 Capaian Ketuntasan Siswa

Gambar 2 menjelaskan hasil belajar kognitif siswa mengenai capaian ketuntasan klasikal. Pembelajaran telah tuntas sekurangnya 85\%. Berdasarkan grafik di atas menunjukkan bahwa siswa mengalami ketuntasan sebesar $85,7 \%$ sehingga dapat dikatakan bahwa kelas telah tuntas secara klasikal. Rata-rata pretest yang diperoleh 45,43 dengan nilai tertinggi 73 dan terendah 18 sedangkan rata-rata posttest 66,78 dengan nilai tertinggi 85 dan terendah 45 . Untuk mengetahui peningkatan hasil belajar dilakukan uji $\mathrm{N}$-gain. Hasil peningkatan dapat dilihat pada gambar 3 berikut: 


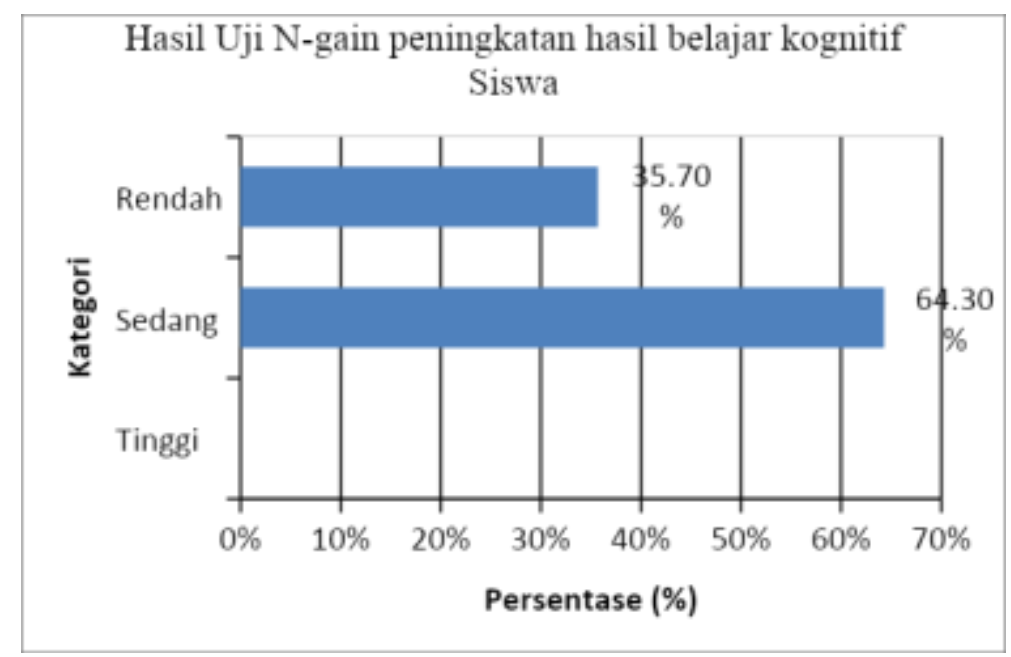

Gambar 3 Hasil Uji N-gain Belajar Kognitif Siswa

Berdasarkan gambar 3 di atas diperoleh peningkatan rata-rata kategori sedang sebesar 64,3\% dan pada kategori rendah sebesar 35,7\% dengan nilai rata-rata $\mathrm{N}$-gain 0,381 kategori peningkatan sedang.

\section{Analisis Angket Minat Belajar Siswa}

Tabel 1 mengenai angket minat belajar siswa disajikan sebagai berikut:

\begin{tabular}{lllll}
\hline \multirow{2}{*}{ Indikator } & \multicolumn{2}{l}{ Persentase $\mathbf{( \% )}$} & & \\
\cline { 2 - 5 } & Sebelum & Kategori & Sesudah & Kategori \\
\hline Perasaan senang & 60.04 & Sedang & 70.98 & Tinggi \\
Keterlibatan siswa & 58.33 & Sedang & 65.08 & Tinggi \\
Perhatian siswa & 61.31 & Tinggi & 66.43 & Tinggi \\
Keterlibatan siswa & 57.39 & Sedang & 67.09 & Tinggi \\
Kesadaran siswa & 65.36 & Tinggi & 68.93 & Tinggi \\
Rata-rata & 60.1 & Sedang & 67.37 & Tinggi \\
\hline
\end{tabular}

Berdasarkan tabel 1 di atas, terdapat 5 indikator yang digunakan untuk mengukur minat belajar siswa. Pada awal treatment diperoleh rata-rata 60,1 kategori sedang kemudian akhir treatment meningkat menjadi rata-rata 67,37 kategori tinggi. Dari tanggapan siswa terhadap pembelajaran materi mikroorganisme menggunakan model TGT 92,86\% memberikan tanggapan baik atau setuju sedangkan 7,14\% memberikan tanggapan cukup baik. Pengamatan aktivitas belajar siswa terhadap pembelajaran dapat dilihat pada tabel 2 . 
Tabel 2 Aktivitas Siswa dalam Pembelajaran

\begin{tabular}{llll}
\hline Pertemuan & Skor & Rerata & Kategori \\
& & $(\%)$ & \\
\hline 0 & 57 & 29.08 & Kurang aktif \\
1 & 94 & 47.96 & Cukup aktif \\
2 & 123 & 62.75 & aktif \\
\hline
\end{tabular}

Berdasarkan tabel 2 di atas diperoleh bahwa pertemuan awal aktivitas tergolong kurang aktif. Kemudian pada pertemuan 1 dan 2 mengalami peningkatan rata-rata dari $47.96 \%$ yang termasuk kategori cukup aktif menjadi aktif dengan rata-rata persentase $62.75 \%$.

\section{PEMBAHASAN}

\section{Hasil Belajar Kognitif Siswa}

Sebelum dilakukan penerapan pembelajaran model Teams Games Tournament (TGT) peneliti mengadakan tes awal berupa pemberian pretest untuk mengukur pemahaman materi siswa. Dari hasil pretest sebagian besar siswa masih tergolong rendah dengan rata-rata nilai 45,43 dengan nilai tertinggi 73 dan nilai terendah 43 . Berdasarkan data tersebut bahwa tes awal banyak siswa yang belum memenuhi kriteria ketuntasan minimal (KKM) sebesar 60 dengan jumlah siswa yang dinyatakan tuntas yakni 2 siswa. Pada hasil posttest diperoleh rata-rata nilai sebesar 66,78 yang termasuk ke dalam kategori tinggi dengan nilai tertinggi 85 dan nilai terendah 45. Dari hasil posttest tersebut, sebanyak 12 siswa telah dinyatakan tuntas dengan persentase 85,7\% sedangkan 2 siswa dinyatakan belum tuntas. Amin dkk. (2018) dalam penelitiannya bahwa ketuntasan belajar secara klasikal dalam suatu kelas telah tuntas belajar jika sekurang-kurangnya 85\% dari jumlah siswa. Hal ini menunjukkan bahwa kelas tersebut telah tuntas secara klasikal sehingga dapat dikatakan bahwa pembelajaran memenuhi kriteria keberhasilan.

Berdasarkan hasil pretest dan posttest yang telah diperoleh kemudian dilakukan analisis uji $\mathrm{N}$-gain. Uji $\mathrm{N}$-gain digunakan untuk mengetahui peningkatan hasil belajar siswa setelah pelaksanaan model pembelajaran TGT. Dari analisis uji N-gain diperoleh bahwa sebanyak 64,3\% siswa mengalami peningkatan dalam kategori sedang dan $35,7 \%$ mengalami peningkatan dalam kategori rendah sehingga diperoleh rata-rata hasil uji Ngain sebesar 0,381 yang termasuk dalam kategori sedang. Dari data yang telah diperoleh 
tersebut dapat dikatakan bahwa pembelajaran model Teams Games Tournament (TGT) memberikan pengaruh positif dalam hasil belajar siswa pada materi mikroorganisme yaitu terjadi peningkatan rata-rata nilai dari pretest ke posttest. Hal ini diperkuat dengan beberapa penelitian diantaranya penelitian yang telah dilakukan oleh Kusumaningrum dkk. (2014) mengatakan bahwa penerapan model pembelajaran Teams Games Tournament (TGT) dapat meningkatkan hasil belajar mata pelajaran IPA daripada dengan menggunakan pembelajaran konvensional. Begitu pula, hasil penelitian yang dilakukan oleh Saoda dkk. (2014) bahwa dengan menggunakan model pembelajaran TGT pada konsep struktur dan fungsi jaringan pada tumbuhan dapat meningkatkan hasil belajar siswa dari rata-rata 47,83 yang kemudian mengalami peningkatan menjadi 86,96.

Hasil belajar siswa dapat meningkat karena telah mengalami pengalaman belajar yang dilakukan selama pelaksanaan pembelajaran pada materi mikroorganisme melalui model pembelajaran TGT. Proses pembelajaran dikemas dalam kegiatan permainan sehingga menyenangkan bagi siswa untuk belajar. Rifa'i \& Anni (2012) mengungkapkan bahwa hasil belajar merupakan perubahan perilaku yang diperoleh siswa setelah mengalami kegiatan belajar. Selama proses tersebut, guru harus memberikan pembelajaran yang menyenangkan bagi siswa sehingga didapat hasil yang maksimal.

Pembelajaran Teams Games Tournament (TGT) merupakan pembelajaran yang dilakukan secara berkelompok yang berbeda tingkat kemampuan dan jenis kelamin tanpa ada perbedaan antar siswa dan bekerja sama untuk mempersiapkan tiap anggota dalam menghadapi turnamen. Turnamen merupakan ciri khas dari model TGT yang di dalamnya terdapat permainan yang dilakukan oleh siswa. Dalam turnamen, siswa menjawab pertanyaan undian yang sudah dipersiapkan oleh guru. Guru kemudian menghitung skor yang diperoleh tiap kelompok yang mewakili dalam meja turnamen. Setelah permainan selesai, guru kemudian memberikan penghargaan kepada kelompok yang menang atau memperoleh skor paling tinggi.

\section{Minat belajar siswa}

Angket minat belajar siswa digunakan untuk mengetahui minat belajar siswa dengan menerapkan model pembelajaran Teams Games Tournament (TGT). Angket ini diberikan sebelum dan sesudah treatment. Dalam penelitian ini terdapat 5 indikator yang digunakan untuk mengukur minat belajar siswa diantaranya: (1) perasaan senang, (2) perhatian, (3) ketertarikan, (4) keterlibatan, dan (5) kesadaran. 
Perasaan senang ditunjukkan dengan adanya perasaan suka atau tidak ada perasaan terpaksa dalam mempelajari. Perhatian ditunjukkan dengan siswa berkonsentrasi dalam mengikuti pembelajaran dan pikirannya tetap fokus dengan apa yang dipelajari. Ketertarikan ditunjukkan dengan adanya daya gerak yang mendorong siswa untuk merasa tertarik dalam kegiatan pembelajaran. Keterlibatan ditunjukkan dengan siswa melakukan atau mengerjakan kegiatan dari objek yang ada dalam pembelajaran. Kemudian kesadaran ditunjukkan dengan siswa mempersiapkan pembelajaran dengan matang yang ditandai dengan siswa belajar sebelum pembelajaran dimulai, siswa tidak terlambat berangkat ke sekolah dan dalam kondisi siap belajar. Pendapat Wahyudin dkk. (2010) bahwa minat merupakan faktor intrinsik yang ada pada diri seseorang yang dapat berpengaruh terhadap hasil belajar seseorang bagi seorang siswa yang berminat pada suatu mata pelajaran akan cenderung bersungguh-sungguh.

Berdasarkan data yang diperoleh dalam penelitian sebelum treatment minat belajar siswa dalam kategori sedang dengan rata-rata 60,1 sedangkan setelah treatment minat siswa mengalami peningkatan menjadi rata-rata 67,37 dengan kategori tinggi. Dari data yang diperoleh menunjukkan bahwa pembelajaran model Teams Games Tournament (TGT) berpengaruh positif dalam minat belajar siswa. Dari hasil data rata-rata indikator yang paling tinggi adalah perasaaan senang yakni sebesar 70,98 siswa menyatakan dalam kondisi merasa senang. Hal ini sejalan dengan pendapat Muldayanti (2013) bahwa adanya permainan yang dirancang dalam pembelajaran TGT dapat meningkatkan dan menumbuhkan minat belajar siswa karena pembelajaran TGT terdapat unsur permainan yang menjadikan proses pembelajaran akan lebih menyenangkan. Kemudian dari hasil minat tersebut, indikator yang paling rendah adalah ketertarikan siswa yaitu sebesar $65,08 \%$, namun dari data hasil penelitian menunjukkan bahwa indikator ketertarikan mengalami peningkatan dari kategori sedang menjadi tinggi. Hal ini menunjukkan bahwa sebagian besar siswa memiliki rasa ketertarikan yang tinggi.

Selama pembelajaran berlangsung dilakukan pengamatan aktivitas belajar siswa. Data aktivitas dilakukan sebagai data pendukung dalam pelaksanaan pembelajaran. Hasil penelitian diperoleh bahwa sebelum dilakukan perlakuan rata-rata aktivitas belajar siswa yaitu 29,08\% dalam kategori kurang aktif kemudian mengalami peningkatan pada perlakuan pertama menjadi $47,96 \%$ yang dikategorikan cukup aktif dan selanjutnya pada pertemuan kedua meningkat menjadi $62,76 \%$ yang dikategorikan bahwa aktivitas belajar 
siswa tergolong aktif. Hal ini disebabkan berdasarkan hasil observasi menunjukkan bahwa siswa merasa antusias dalam mengikuti turnamen. Sejalan dengan pendapat yang disampaikan Purnamawati dkk. (2014) bahwa dalam model pembelajaran TGT adanya permainan yang dikemas dalam turnamen akan membuat siswa terlibat aktif dalam belajar.

Data hasil aktivitas tersebut diperkuat dengan hasil tanggapan siswa mengenai aktivitas belajar dengan rata-rata siswa memberikan tanggapan baik sejumlah 92,86\% dan siswa yang memberikan tanggapan cukup baik sejumlah 7,14\%. Secara keseluruhan siswa memberikan tanggapan baik atau setuju terhadap pembelajaran yang menggunakan model Temas Games Tournament (TGT). Hasil ini sejalan dengan pendapat Jannah \& Leonard (2018) bahwa model pembelajaran TGT merupakan sistem pembelajaran kooperatif dan interaktif yang mudah digunakan dan dapat membuat siswa menjadi lebih aktif dalam belajar. Penelitian yang dilakukan Agustian dkk. (2018) bahwa penerapan model pembelajaran Teams Games Tournament (TGT) dapat meningkatkan aktivitas belajar siswa dalam mata pelajaran sistem bahan bakar bensin dari kriteria aktivitas cukup 50,6\% mengalami peningkatan menjadi 76,3\% dengan kriteria aktivitas siswa tinggi.

Pada awal observasi aktivitas siswa belum terlihat walaupun telah dilakukan pembelajaran biasa. Kemudian pada observasi pembelajaran kedua, aktivitas siswa menjadi meningkat karena siswa melakukan diskusi kelompok. Pada observasi yang kedua ini peningkatan aktivitas belum begitu terlihat tetapi sudah menunjukkan beberapa siswa yang aktif bertanya dan sebagian siswa juga menperhatikan penjelasan dari guru. Dari presentasi kelompok masih terdapat beberapa siswa yang tidak menyampaikan pendapat di depan kelas. Hal ini terjadi karena hanya siswa yang pandai yang berani menyampaikan presentasi dengan menggunakan bahasa inggris sedangkan siswa yang kurang pandai merasa malu sehingga kurang aktif dalam berpartisipasi. Pada observasi yang terakhir menunjukkan bahwa aktivitas siswa mengalami peningkatan menjadi kategori aktif. Hal ini diperoleh bahwa sebagian besar siswa menjawab pertanyaan tournament, siswa juga memperhatikan penjelasan dari guru dan adanya tournament memberikan kesempatan bagi semua siswa untuk aktif berpartisipasi yang ditunjukkan dengan keantusiasan siswa dalam mengikuti tournament. Hal ini didukung dengan data angket minat belajar siswa akan keterlibatan siswa yaitu bahwa indikator keterlibatan siswa tergolong tinggi. Sejalan dengan penelitian Sari dkk. (2012) menyatakan bahwa 
penerapan model pembelajaran TGT berpengaruh positif terhadap peningkatan aktivitas belajar siswa, siswa menjadi tertantang, siswa mendapatkan pengalaman langsung, dan memungkinkan siswa belajar lebih rileks, tercipta rasa tanggung jawab, kerja sama, persaingan sehat dan keterlibatan belajar. Pendapat Tyasning dkk. (2012) bahwa model TGT merupakan upaya untuk menciptakan keaktifan semua siswa di dalam kelas sehingga permainan dapat merangsang minat siswa dalam aktivitas kelas sehingga siswa termotivasi dan memiliki minat untuk belajar. Begitu pula dengan pendapat Putrayasa dkk. (2014) yang mengatakan bahwa minat belajar siswa mempengaruhi keantusiasan dan keaktifan siswa dalam proses pembelajaran. Oleh karena itu, dengan minat akan muncul adanya keterlibatan siswa dalam setiap aktivitas terutama dalam pembelajaran.

Minat, aktivitas belajar dan model pembelajaran merupakan sebagian faktor yang mempengaruhi keberhasilan siswa dalam belajar. Banyak faktor lain yang mempengaruhi keberhasilan belajar siswa. Nasrun (2015) mengatakan bahwa hasil belajar dipengaruhi oleh banyak faktor diantaranya faktor internal (intelegensi, minat, bakat, motif, kematangan), faktor eksternal (cara orang tua mendidik anak, pengertian dari orang tua, dan relasi antar anggota keluarga), faktor pendekatan belajar, faktor sekolah (kurikulum, metode mengajar, guru), dan faktor lingkungan masyarakat.

\section{SIMPULAN}

Berdasarkan hasil penelitian yang dilakukan dapat disimpulkan bahwa: (1) penerapan pembelajaran model Teams Games Tournament (TGT) yang dilengkapi dengan LDS memberikan pengaruh positif terhadap hasil belajar kognitif siswa pada materi mikroorganisme di Vaishnavi Secondary School Nepal. Selain itu, berdasarkan data pendukung mengenai aktivitas belajar siswa juga meningkat. Dari hasil tanggapan siswa mengenai aktivitas belajar menyatakan sebagian besar siswa memberikan tanggapan baik atau setuju mengenai penerapan pembelajaran model Teams Games Tournament (TGT). (2) Penerapan model Teams Games Tournament (TGT) berpengaruh positif terhadap minat belajar siswa di Vaishanvi Secondary School Nepal.

Berdasarkan penelitian yang dilakukan saran yang disampaikan untuk seorang guru bahwa keberhasilan penerapan pembelajaran model TGT di Vaishnavi Secondary School Nepal bisa menjadi referensi bagi guru untuk bisa diterapkan di Indonesia agar tercipta suasana belajar yang aktif dan menyenangkan dalam upaya meningkatkan hasil belajar 
siswa kemudian dapat dilakukan penelitian lebih lanjut mengenai pembelajaran Teams Games Tournament (TGT) pada materi lain yang disesuaikan dengan kebutuhan materi pelajaran yang akan diuji.

\section{DAFTAR PUSTAKA}

Agustian, R., Lapisa, R., Tech, \& Fernandez, D. 2018. Penerapan Cooperative Learning Type Teams Games Tournament (TGT) terhadap Hasil Belajar Siswa pada Mata Pelajaran Sistem Bahan Bakar pada Kelas XI di SMK Negeri 1 Sumbar. Automotive Engineering Education Journals. 1(1): 1-10

Amin, T.A., Yahya, M., \& Caronge, M. W. 2018. Penerapan Model Pembelajaran Kooperatif Tipe TGT untuk Meningkatkan Hasil Belajar MembiakkanTanaman Secara Vegetatif pada Siswa Kelas X SMK Negeri 3 Takalar. Jurnal Pendidikan Teknologi Pertanian. 4(7): 73-81.

Astuti, S.P. 2015. Pengaruh Kemampuan Awal dan Minat Belajar terhadap Prestasi Belajar Fisika. Jurnal Formatif, 5(1): 68-75.

Ghalia, F., Masykuri, M., \& Nurhayati, N.D. 2015. Penerapan Model Pembelajaran Teams Games Tournament (TGT) dengan Kartu Destinasi untuk Meningkatkan Aktivitas dan Hasil Belajar Siswa pada Materi Sistem Periodik Unsur Kelas X MIA 3 di SMA Batik 1 Surakarta Tahun Ajaran 2014/2015. Jurnal Pendidikan Kimia (JPK). 4(2): 115-121.

Hamid, S., Mas'ud, A., \& Ahmad,H. 2014. Penerapan Model Pembelajaran Teams Games Tournament (TGT) dalam Meningkatkan Hasil Belajar IPA Biologi Siswa di MTs Negeri Dowora. Jurnal Bioedukasi, 2(2): 221-229.

Jannah, S.R., \& Leonard. 2018. Model Pembelajaran Kooperatif Tipe Teams Games Tournament dengan Strategi Pembelajaran Tugas dan Paksa. Seminar Nasional dan Diskusi Panel Multidisiplin Hasil Penelitian \& Pengabdian Kepada Masyarakat. Hal 491-501.

Kholisho, Yosi N. 2017. Pengembangan Modul Pembelajaran Multimedia untuk Meningkatkan Minat dan Pemahaman Konsep Mahasiswa Prodi Pendidkan Informatika. Jurnal Pendidkan Informatika, 1(1): 17-23.

Kusumaningrum, P.C.A., Parmiti, D.P., \& Wibawa, M. Citra. 2014. Pengaruh Model Pembelajaran Kooperatif Tipe Team Games Tournament (TGT) terhadap Hasil 
Belajar IPA pada Siswa Kelas V Gugus XV Kecamatan Buleleng Tahun Ajaran 2013/2014. Jurnal Mimbar PGSD. 2(1): 1-10.

Maesaroh, S. 2013. Peranan Metode Pembelajaran terhadap Minat dan Prestasi Belajar Pendidikan Agama Islam. Jurnal Kependidikan. 1(1): 150-168.

Marwiyah, S. 2012. Konsep Pendidikan Berbasis Kecakapan Hidup. Jurnal Falasifa. 3(1): 75-97.

Muldayanti, N.D. 2013. Pembelajaran Biologi Model STAD dan TGT Ditinjau dari Keingintahuan dan Minat Belajar Siswa. Jurnal Pendidikan IPA Indonesia, 2(1): 12-17.

Nasrun, A.R. 2015. Psikologi Bealajar. Al-Fikrah: Jurnal Pendidikan Islam, 6.

Nurjanah, S., \& Aman. 2016. Hubungan antara Minat Belajar dan Perhatian Orang Tua dengan Prestasi Belajar Sejarah pada Siswa Kelas XI MIPA SMA Negeri 1 Pakem Tahun Ajaran 2015/2016. Jurnal Pendidikan Sejarah. 5(3): 218-242.

Purnamawati, H., Ashadi, \& Susilowati, E. 2014.Pengaruh Model Pembelajaran Kooperatif Tipe Teams Games Tournament (TGT) dengan Media Kartu dan Ular Tangga Ditinjau dari Kemampuan Analisis Siswa terhadap Prestasi Belajar Siswa pada Materi Pokok Reaksi Redoks Kelas X Semester 2 SMA Muhammadiyah 1 Karanganyar Tahun Pelajaran 2013/2014. Jurnal Pendidikan Kimia. 3(4): 100-108.

Putrayasa, I.M., Syahruddin,H., \& Margunayasa, I.G. 2014. Pengaruh Pembelajaran Discovery Learning dan Minat Belajar terhadap Hasil Belajar IPA Siswa. Jurnal Mimbar PGSD, 2(1): 1-11.

Rifa'i, A., \& Anni,C.T. 2012. Psikologi Pendidikan. Semarang: Pusat Pengembangan MKU/MKDK-LP3.

Saoda, H., Mas'ud, A., \& Ahmad, H. 2014. Penerapan Model Pembelajaran Teams Games Tournament (TGT) dalam Meningkatkan Hasil Belajar IPA Biologi Siswa di MTs Negeri Dowora. Jurnal Bioedukasi. 2(2): 221-229.

Sari, R.E.K., Hadi, S., \& Prishardoyo, B. 2012. Upaya Peningkatan Hasil Belajar dengan Menggunakan Model Pembelajaran Kooperatif Team Games Tournament (Materi permintaan, Penawaran, dan Terbentuknya Harga Pasar). Jurnal Analisi Pendidikan Ekonomi. 1(1): 1-7.

Tyasning, D.M., Haryono, Nurhayati, N.D. 2012. Penerapan Model Pembelajaran TGT (Teams Games Tournaments) Dilengkapi LKS untuk Meningkatkan Aktivitas dan 
Hasil Belajar Materi Minyak Bumi pada Siswa Kelas X-4 SMA Batik 1 Surakarta Tahun Pelajaran 2011/2012. Jurnal Pendidikan Kimia. 1(1): 26-33.

Utami, Y.F., Widiana, R., \& Sari, 1.Y. 2018. Penerapan Model Pembelajaran Problem Based Learning (PBL) disertai Lembar Diskusi Siswa (LDS) terhadap Hasil Belajar Biologi Siswa Kleas VIII di MTsN 5 Kota Padang tahun Pelajaran 2017/2018. Jurnal Pendidikan Biologi STKIP. 1(1): 1-10.

Wahyudin, Sutikno, \& Isa, A. 2010. Keefektifan Pembelajaran Berbantuan Multimedia Menggunakan Metode Inkuiri Terbimbing untuk Meningkatkan Minat dan Pemahaman Siswa. Jurnal Pendidikan Fisika Indonesia. 6(1): 58-62. 